\title{
Kinetic Modelling of Free Energy for Simultaneous Nitrification and Aerobic Denitrification under High Cyanide Environments
}

\author{
Ncumisa Mpongwana, Seteno K. O. Ntwampe*, Boredi S. Chidi and Elizabeth I. Omodanisi
}

\begin{abstract}
The Gibbs free energy is significant to understand simultaneous nitrification and aerobic denitrification $(\mathrm{SNaD})$, it is also imperative to study Gibbs free energy to determine whether or not the reaction is plausible. This study aims to investigate the effect of cyanide $\left(\mathrm{CN}^{-}\right)$on $\mathrm{SNaD}$ when cyanide degrading mix consortia is used. The relationship between the rate of nitrification and Gibbs free energy was also investigated. The results attained show that 37.55 $\mathrm{mg} / \mathrm{L}$ of $\mathrm{CN}$ - does not have an effect on $\mathrm{SNaD}$. The consortia degraded $\mathrm{CN}$ - and achieved $\mathrm{SNaD}$, with degradation efficiency of $92.9 \%, 97.7 \%$ and the degradation rate of 0.0234 and $0.139 \mathrm{mg} / \mathrm{L} / \mathrm{hr}$ for nitrification and $\mathrm{CN}$ - respectively. Moreover, all the free Gibbs energy was found to be negative, with the lowest Gibbs free energy being -756.4 and $-1830.9 \mathrm{Kcal} / \mathrm{mol}$ for nitritation and nitratation in the first $48 \mathrm{hr}$ of the reaction respectively. Additionally, a linear relationship between the rate of $\mathrm{NH} 4-\mathrm{N}$ and $\mathrm{NO}_{2}$ - degradation with their respective Gibbs free energy was observed. Linear model was also used to predict the relationship between $\mathrm{NH}_{4}-\mathrm{N}, \mathrm{NO}_{2}{ }^{-}$degradation and Gibbs free energy. The results obtained showed a good correlation between the models and the experimental data with correlation efficiency being 0.94 and 0.93 for nitritation, and nitratation respectively. From the results found it can be deduced that $\mathrm{SNaD}$ is plausible under high cyanide conditions when cyanide degrading or tolerant microorganisms are employed. This can be a sustainable solution to $\mathrm{SNaD}$ inhibition by $\mathrm{CN}^{-}$compounds during wastewater treatment.
\end{abstract}

Keywords - Cyanide, Denitrification, nitrification and Gibbs free energy.

\section{INTRODUCTION}

Cyanide $(\mathrm{CN}-)$ is a toxic compound known to inhibit most biological process that is being performed in wastewater treatment plants (WWTP). Nitrification and denitrification are among the process that are heavily affected by $\mathrm{CN}$ - compounds [1], [2]. Remedial procedures such as the use of activated carbon have been recognized to eradicate inhibition effect of toxic compounds on nitrification and denitrification; however, the use of activated carbon is not feasible in $\mathrm{CN}$ - containing

Manuscript received 09 October 2019. This work was supported by Cape Peninsula University of Technology, University Research Fund (URF RK16). All Authors are with Bioresource Engineering Research Group (BioERG), Faculty of Applied Sciences, and Department of Chemical Engineering, Cape Peninsula University of Technology, Keizersgracht and Tennant Street, Zonnebloem, P.O. Box 652, Cape Town, 8000, South Africa. wastewater due to its low absorption capability; furthermore, the use of activated carbon may also result in additional costs [2]. Reference [3] proposed that cyanide degrading bacteria must be employed to eliminate the inhibition effect of $\mathrm{CN}$ toward nitrification and denitrification. Reference [4] has proven the feasibility of using cyanide degrading bacteria as a remedial option for inhibition of nitrification and denitrification by $\mathrm{CN}-$. However, the application of cyanide degrading microorganisms is not yet established in a large scale WWTP due to fear of irretrievable process failure, thus more information that will ease the process control is still required. This study investigates the thermodynamics to understand the simultaneous nitrification and aerobic denitrification ( $\mathrm{SNaD}$ ) by cyanide degrading consortium in the presence of high $\mathrm{CN}$ conditions. The Gibbs free energy of nitritation and nitratation were investigated since nitritation is known to be a rate-limiting step. A linear relationship is known to exist between the rate of biochemical reaction and their respective free energies [5]. The Gibbs free energy was selected for this study since it is known to be a driving force of a reaction. The reaction is judged based on the principles of whether the reaction is spontaneous $(\Delta \mathrm{G}<0)$, at equilibrium $(\Delta \mathrm{G}=0)$ and impossible if $(\Delta \mathrm{G}>0)[6]$.

\section{MATERIALS AND METHODS}

\section{A. Isolation and Inoculum Development}

The consortia were isolated from $\mathrm{CN}$ - containing waste at the Bioresource Engineering research group (BioERG), Cape Peninsula University of Technology (CPUT). They were cultured into a complex media at sterile conditions for 5 days; thereafter, it was transferred into $100 \mathrm{ml}$ of basal media containing: $7.9 \mathrm{~g} \mathrm{Na}_{2} \mathrm{HPO}_{4}, 1.5 \mathrm{~g} \mathrm{KH}_{2} \mathrm{PO}_{4}, 0.5 \mathrm{~g} \mathrm{MgSO}_{4} .7 \mathrm{H}_{2} \mathrm{O}$ and $1 \mathrm{~mL}$ trace elemental solution. The trace elemental solution was composed of: $1.1 \mathrm{~g}\left(\mathrm{NH}_{4}\right)_{6} \mathrm{Mo}_{7} \mathrm{O}_{2} \cdot 4 \mathrm{H}_{2} \mathrm{O}, 50 \mathrm{~g}$ EDTA, $2.2 \mathrm{~g}$ $\mathrm{ZnSO}_{4} .7 \mathrm{H}_{2} \mathrm{O}$, $5.5 \mathrm{~g} \mathrm{CaCl}_{2}, 5.0 \mathrm{~g} \mathrm{FeSO}_{4} .7 \mathrm{H}_{2} \mathrm{O}, 5.06 \mathrm{~g}$ $\mathrm{MnCl}_{2} \cdot 4 \mathrm{H}_{2} \mathrm{O}, 1.61 \mathrm{~g} \mathrm{CoCl}_{2} \cdot 6 \mathrm{H}_{2} \mathrm{O}, 1.57 \mathrm{~g} \mathrm{CuSO}_{4} .5 \mathrm{H}_{2} \mathrm{O}$ (per liter). The consortia were incubated at $36.5^{\circ} \mathrm{C}$ for $48 \mathrm{hrs}$ and was used as an inoculum for the reactor experiment.

\section{B. Reactor Experimental Runs}

The basal media as indicated above was used for the reactor experiment. $1 \mathrm{~L}$ reactor was used for this experiment. It was inoculated with $10 \%$ of the $48 \mathrm{hrs}$ culture and the 
microorganisms were grown for 5 days, the contaminants were added on day 6 . The $\mathrm{pH}$ and temperature were maintained at 6.5 and $36.5^{\circ} \mathrm{C}$ throughout the experiment respectively. A concentration, i.e. 285 and $37.55 \mathrm{mg} / \mathrm{L}$ of $\mathrm{NH}_{4}-\mathrm{N}$ and $\mathrm{CN}^{-}$were then added to the reactors, respectively. After the addition of the toxicant, the reactors were tightly closed and covered with foil to avoid ammonium stripping and volatilization of $\mathrm{CN}^{-}$. Samples were collected every $24 \mathrm{hrs}$ to analyze residual $\mathrm{CN}^{-}$, $\mathrm{NH}_{4}{ }^{-} \mathrm{N}, \mathrm{NO}_{2}{ }^{-}$and $\mathrm{NO}_{3}{ }^{-}$using test kits obtained from Merck SA and Merck ANOVA Spectroquant. All the analysis was performed in duplicates.

\section{Bioenergetic/Thermodynamic Models}

The free energy $(\Delta G)$ equation for nitrification can be expressed as:

$$
\begin{aligned}
& \mathrm{NH}_{4}-\mathrm{N}+1.05_{2} \rightarrow \mathrm{NO}_{2}^{-}+\mathrm{H}^{+} \Delta G=65+ \\
& R T \ln \left\{\frac{\left[\mathrm{NO}_{2}^{-}\right]\left(10^{-\mathrm{PH}^{2}}\right)^{\mathrm{2}}}{\left[\mathrm{NH}_{4}-N\right]\left[\mathrm{O}_{2}\right]^{1.5}}\right\}
\end{aligned}
$$

$$
\left.\mathrm{NO}_{2}^{-}+0.5_{2} \rightarrow \mathrm{NO}_{3}^{-} \Delta G=18.5+R T \ln \left\{\frac{\left[\mathrm{NO}_{3}^{-}\right]}{\left[\mathrm{NO}_{2}^{-}\right]\left[\mathrm{O}_{2}\right]}\right]^{0.5}\right\}
$$

Where $\Delta \mathrm{G}$ is a free energy change in $\mathrm{Kcal} / \mathrm{mol}, \mathrm{NH}_{4}-\mathrm{N}$ is molar concentration of ammonium ions, $\mathrm{NO}_{2}^{-}$is molar concentration of $\mathrm{NO}_{2}^{-}$and $\mathrm{O}_{2}$ is a molar concentration of oxygen gas, $\mathrm{R}$ is the universal gas constant and $\mathrm{T}$ is temperature. However, when the experiment is operated at steady state with constant Temperature, $\mathrm{pH}$ and abundance of $\mathrm{O}_{2}$ Eq. (1) and (2) becomes:

$$
\begin{aligned}
& \Delta G=65+R T \ln \left(\frac{\left[\mathrm{NO}_{2}\right]}{\left[\mathrm{NH}_{4}-\mathrm{N}\right]}\right) \\
& \Delta G=18.5+R T \ln \left(\frac{\left[\mathrm{NO}_{\mathrm{g}}\right]}{\left[\mathrm{NO}_{2}\right]}\right)
\end{aligned}
$$

The model used to estimate the rates in respect to their corresponding Free energies is as explained by [7]. The model assumes that when nitrifying bacteria remain constant then the rate of microbial growth could be described as a function of $\Delta \mathrm{G}$, therefore:

$$
\mu=F \Delta G
$$

Where $\mu$ is a growth rate, $F$ is a linear function. However $\mu=$ $(1 / X)(d x / d t)$ and $Y=d x / d t, d s / d t$ the equation can be rearranged as follow:

$$
\frac{d s}{d t}=\frac{X}{Y} F \Delta G
$$

Where $X$ is biomass concentration and $Y$ is biomass yield. At steady state and when the bacterial yield is constant the equation can be rearranging as:

$$
\frac{d s}{d t}=F \Delta G
$$

The value of $\Delta \mathrm{G}$ was determined as using with equation 3 and 4, thereafter, Eq. 7 was for linear regression using polymath 10.0 .

\section{RESULTS AND DISCISSION}

An experiment was conducted to study the effect of high $\mathrm{CN}$ concentrations on the ability of cyanide degrading mix consortia to achieve $\mathrm{SNaD}$. The experiment was conducted in a batch reactor. The results obtained reveal that $37.55 \mathrm{mg} / \mathrm{L}$ of $\mathrm{CN}$ - did not affect the $\mathrm{SNaD}$. The consortia rapidly degraded $\mathrm{CN}$ - from 37.55 to $12 \mathrm{mg} / \mathrm{L}$ in the first $48 \mathrm{hrs}$ of the experiment. This could be a defensive mechanism for the consortia to detoxify the $\mathrm{CN}$ - concentration into less toxic concentrations. The consortia achieved nitrification, denitrification and cyanide degradation simultaneously.

The degradation efficiency over $288 \mathrm{hrs}$ was found to be $92.9 \%, 97.7 \%$ with the degradation rate of 0.0234 and 0.139 $\mathrm{mg} / \mathrm{L} / \mathrm{hr}$ for nitrification and $\mathrm{CN}^{-}$degradation respectively. The removal efficiency found in this study is greater than that of a study conducted by [2]. Furthermore, [3] found similar results when using cyanide degrading bacteria for nitrification subsequent denitrification. However, the conversion of $\mathrm{NH}_{4}-\mathrm{N}$ to $\mathrm{NO}_{2}{ }^{-}$did not make a stoichiometric logic as the concentration of $\mathrm{NH}_{4}-\mathrm{N}$ used did not correspond with the $\mathrm{NO}_{2}{ }^{-}$produced. This phenomenon could be an indication of the residual $\mathrm{NO}_{2}{ }^{-}$being used for microbial proliferation or may be caused by high nitrite reductase which rapidly converts $\mathrm{NO}_{2}{ }^{-}$into $\mathrm{NO}_{3}{ }_{3}^{-}$. Jin et al. [8] also found similar results in a study conducted using Pseudomonas sp. ADN-42 for Heterotrophic SNaD under saline conditions. The existence of denitrification was demonstrated by the decrease in the $\mathrm{NO}_{3}^{-}$-see Fig. 1. Nevertheless, the production of the nitrogenous gasses was not examined during this study.

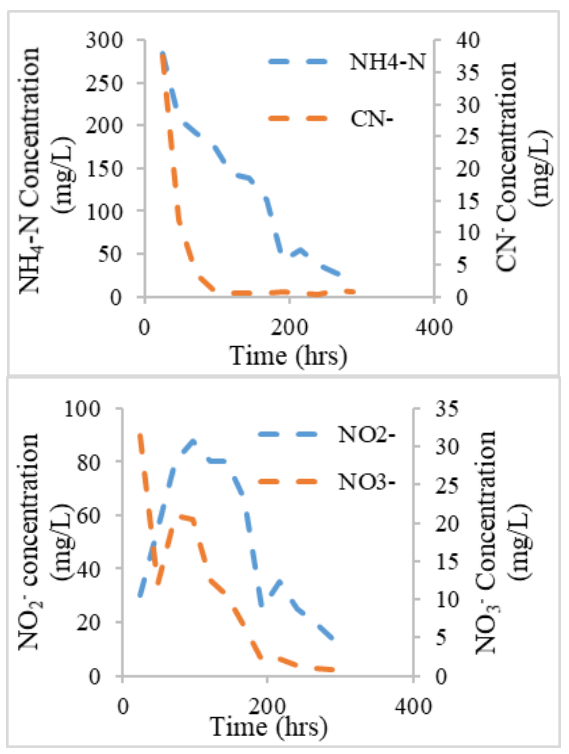

Fig. 1. graphs representing simultaneous nitrification, denitrification, and cyanide degradation. A: nitrification and Cyanide degradation. B: $\mathrm{NO}_{2}{ }^{-}$and $\mathrm{NO}_{3}{ }^{-}$accumulation and degradation. 
TABLE I: MODEL VARIABLES FOR NITRITATION AND NITRATATION

\begin{tabular}{cccccc}
\hline \hline Model & $\mathrm{F}$ & $\mathrm{a}$ & $\mathrm{R}^{2}$ & variance & $\mathrm{R}^{2} \mathrm{adj}$ \\
\hline$\frac{\mathrm{d}\left[\mathrm{NH} \mathrm{H}_{\mathrm{g}}-\mathrm{N}\right]}{\mathrm{dt}}=F \Delta G$ & -0.0001 & - & 0.93 & 0.0001 & 0.93 \\
$\frac{\mathrm{d}\left[\mathrm{NO}_{2}^{-}\right]}{d t}=F \Delta G+\alpha$ & 0.001 & 1.85 & 0.93 & 0.0140 & 0.93 \\
\hline \hline
\end{tabular}

Gibbs free energy $(\Delta \mathrm{G})$ was plot as a function of $\left[\mathrm{NO}_{2}{ }^{-}\right] /\left[\mathrm{NH}_{4}-\mathrm{N}\right]$ and $\left[\mathrm{NO}_{3}{ }^{-}\right] /\left[\mathrm{NO}_{2}{ }^{-}\right]$, all the valued of Gibbs free energy were found to be negative for both nitritation and nitratation. This is an indication of thermodynamic feasibility and the spontaneity of nitritation and nitratation under the $\mathrm{CN}$ conditions $[9,10]$. At the beginning of the experiment, the Gibbs free energy was low with the lowest free energy of -756.4 and $-1830.9 \mathrm{Kcal} / \mathrm{mol}$ for nitritation and nitratation respectively. This shows that the reaction was more rapid at the beginning of the experiment [11], as the concentration of the toxicant becomes exhausted the free Gibbs energy increases. It has been documented that when a rate of reaction has a strongly negative $\Delta \mathrm{G}$ values, it implies that they are kinetically controlled, meaning they are feasible in wide concentration ranges, this is more likely to occur in oxidation reaction with stronger electron accepter like oxygen and nitrate [12].

This could also be linked with microorganisms reaching the stationary phase, thus the decrease in energy. Literature claims that there's a linear relationship exist between biochemical reaction with their corresponding $\Delta G$ [5], The relationship between the rate of $\mathrm{NH}_{4}-\mathrm{N}$ and $\mathrm{NO}_{2}^{-}$degradation and their corresponding $\Delta \mathrm{G}$ was studied and it was apparent that there is a linear correlation between the rate of $\mathrm{NH}_{4}-\mathrm{N}$ and $\mathrm{NO}_{2}{ }^{-}$ degradation and their corresponding $\Delta \mathrm{G}$. Lüttge et al. [13], also reported a linear relationship between the rate of albite dissolution and their corresponding $\Delta \mathrm{G}$. Furthermore, the Linear models were used to predict the relationship between the rate of $\mathrm{NH}_{4}-\mathrm{N}$ and $\mathrm{NO}_{2}{ }^{-}$degradation with their corresponding $\Delta \mathrm{G}$. the model fitted well into the experiment with correlation coefficient of 0.94 and 0.93 for nitritation and nitratation respectively. Additionally, the observed rate of NH4-N and $\mathrm{NO}_{2}^{-}$degradation was plotted against the predicted rate of degradation for both $\mathrm{NH}_{4}-\mathrm{N}$ and $\mathrm{NO}_{2}{ }^{-}$, the result showed that the observed rate and the predicted rate had a good linear

\section{Model: Change $=\mathrm{F}^{*} \mathrm{G}$}

Parity plot

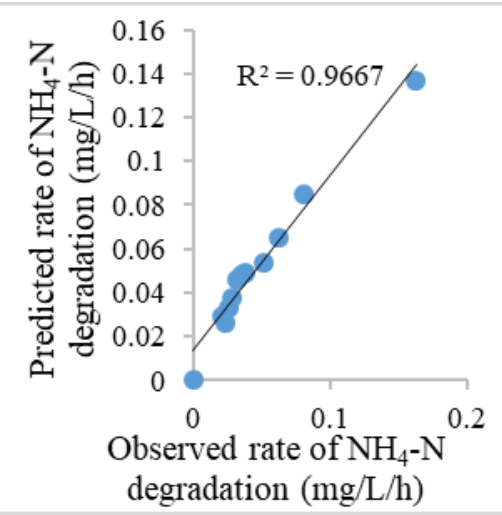

Simulation of the model

$\Delta \mathrm{G}$ as a function of

[product]/[reactan t]
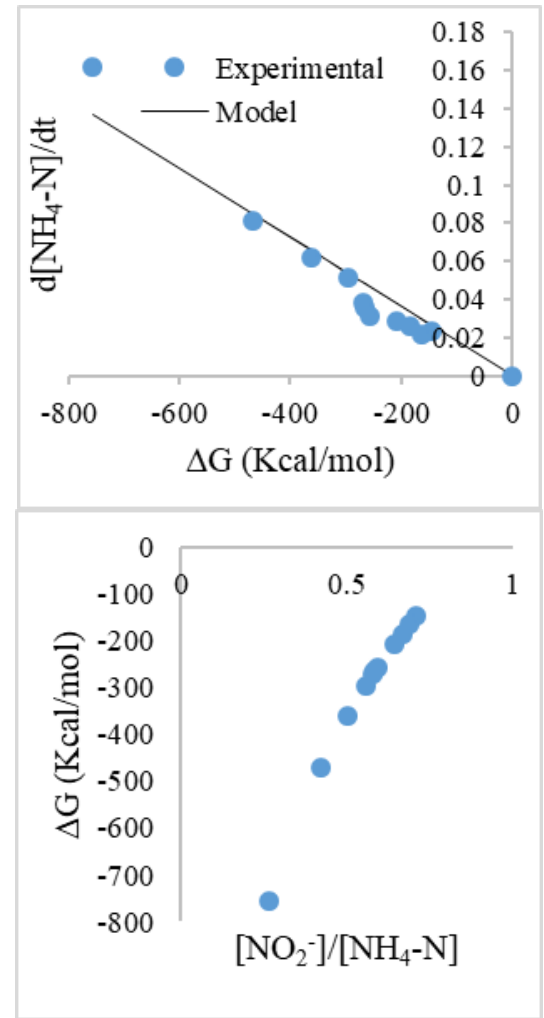

Fig. 2. Parity plots of predicted rate nitritation values versus experimental values. simulations of the linear model data into a rate of $\mathrm{NH}_{4}-\mathrm{N}$ degradation versus Gibbs free energy data and $\Delta \mathrm{G}$ as a function of [product]/[reactant].

correlation with the correlation coefficient of 0.97 and 0.93 for nitritation and nitratation respectively- Fig 2 and 3.

\section{CONCLUSION}

The isolated consortia presented an interesting characteristic, it performed nitrification, denitrification and degraded $\mathrm{CN}^{-}$ simultaneously. The Gibbs free energy was also studied to confirm the feasibility of the nitrification denitrification under high $\mathrm{CN}^{-}$conditions. Negative $\Delta \mathrm{G}$ were obtained for both nitratation and nitritation, this indicated that the reactions are feasible, spontaneous and rapid. Furthermore, the relationship between the rate of $\mathrm{NH}_{4}-\mathrm{N}$ and $\mathrm{NO}_{2}{ }^{-}$degradation and $\Delta \mathrm{G}$ was investigated, the results showed that there is a linear correlation between rate of $\mathrm{NH}_{4}-\mathrm{N}$ and $\mathrm{NO}_{2}^{-}$degradation and their respective $\Delta \mathrm{G}$. The equilibrium constant was also investigated (results not shown) since the nature of equilibrium constant can also articulate whether the reaction is spontaneous or not, an increase in equilibrium constant with the decrease in $\Delta \mathrm{G}$ was observed, this is also a proof that $\mathrm{SNaD}$ reaction occurs spontaneously and does not require additional energy. 
Model: Change $=\mathrm{a}+\mathrm{F} * \mathrm{G}$

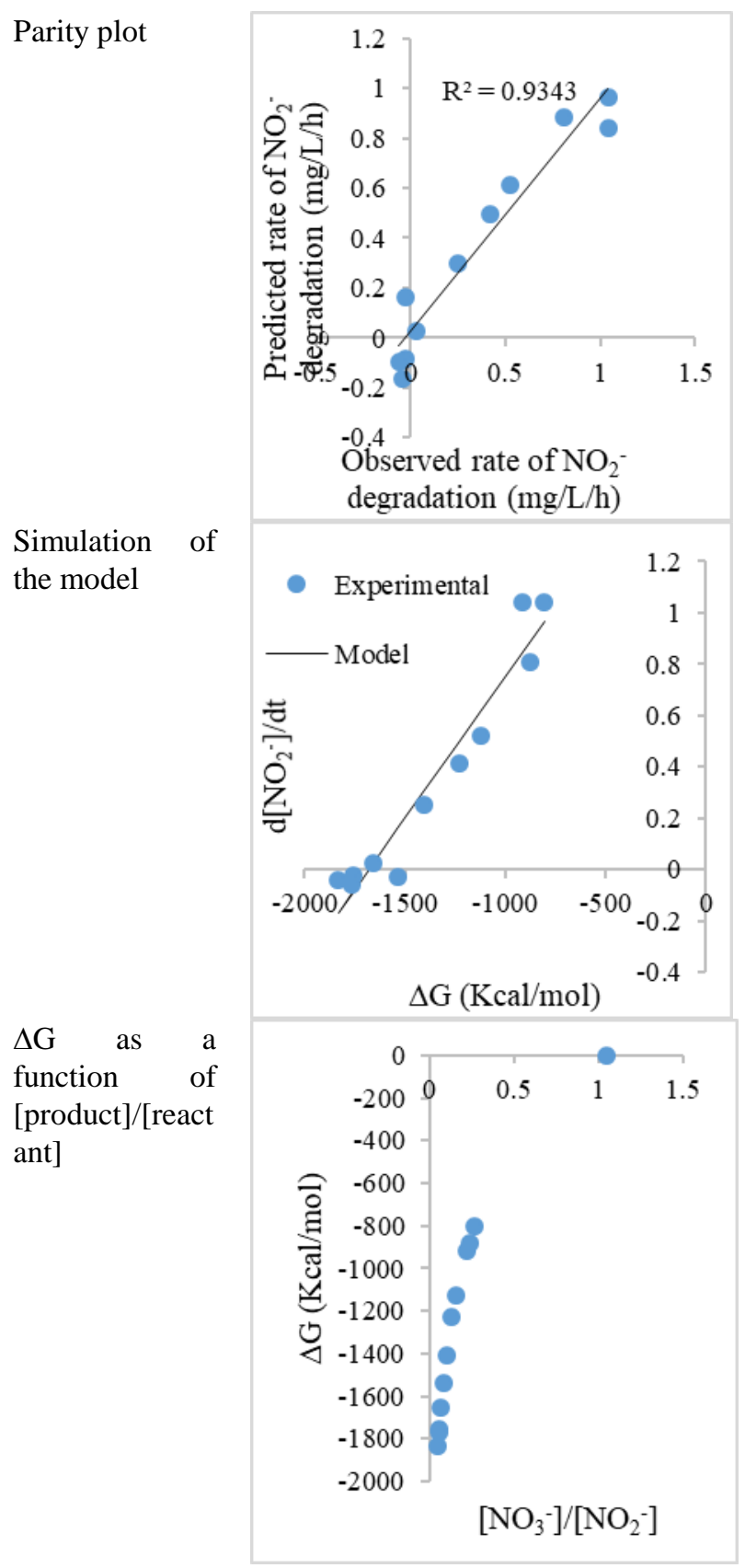

Fig. 3. Parity plots of predicted rate nitratation values versus experimental values. simulations of the linear model data into a rate of NH4-N degradation versus Gibbs free energy data and $\Delta \mathrm{G}$ as a function of [product]/[reactant].

\section{ACKNOWLEDGMENT}

The authors would like to acknowledge the financial assistance from the Cape Peninsula University of Technology, University Research Fund (URF RK16).

\section{REFERENCES}

[1] Kapoor, V., Elk, M;Li, X and Santo Domingo, J. Inhibitory effect of cyanide on wastewater nitrification determined using SOUR and
RNA-based gene-specific assays. Lett Appl Microbiol, vol 63, no. 2, pp.155-161, June 2016

https://doi.org/10.1111/lam.12603

[2] Kim, Y., Park, D., Lee, D and Park, J. Inhibitory effects of toxic compounds on nitrification process for cokes wastewater treatment. $J$ Hazard Mater, vol. 152, no. 3, pp.915-921, April 2008.

https://doi.org/10.1016/j.jhazmat.2007.07.065

[3] Han, Y., Jin, X., Wang, Y., Liu, Y and Chen, X. Inhibitory effect of cyanide on nitrification process and its eliminating method in a suspended activated sludge process. Environ sci pollut $r$, vol. 21, no. 4, pp.2706-2713, October 2013.

https://doi.org/10.1007/s11356-013-2226-4

[4] Mpongwana, N., Ntwampe, S., Mekuto, L., Akinpelu, E., Dyantyi, S and Mpentshu, Y. Isolation of high-salinity-tolerant bacterial strains, Enterobacter sp., Serratia sp., Yersinia sp., for nitrification and aerobic denitrification under cyanogenic conditions. Water Sci Technol, vol. 73, n. 9 , pp. 2168-75, February 2016. https://doi.org/10.2166/wst.2016.070

[5] Rottenberg, $\mathrm{H}$ and Gutman, $\mathrm{M}$. Control of the rate of reverse electron transport in submitochondrial particles by the free energy. Biochem $J$, vol. 16, no. 14, pp.3220-3227, July 1977.

https://doi.org/10.1021/bi00633a028

[6] Zhang, T., Ding, L., Ren, H., Guo, Z and Tan, J. Thermodynamic modeling of ferric phosphate precipitation for phosphorus removal and recovery from wastewater. J Hazard Mater, vol. 176, no.1-3, pp.444-450, April 2010 . https://doi.org/10.1016/j.jhazmat.2009.11.049

[7] Mirbagheri, S., Poshtegal, $M$ and Parisai, M. Removing of urea and ammonia from petrochemical industries with the objective of reuse, in a pilot scale: Surveying of the methods of waste water treatment. Desalination, vol. 256, no. 1-3, pp.70-76, June 2010. https://doi.org/10.1016/j.desal.2010.02.011

[8] Jin, R., Liu, T., Liu, G., Zhou, J., Huang, J and Wang, A. Simultaneous Heterotrophic Nitrification and Aerobic Denitrification by the Marine Origin Bacterium Pseudomonas sp. ADN-42. Applied Biochemistry and Biotechnology, vol. 175, no. 4, pp.2000-2011, November 2014. https://doi.org/10.1007/s12010-014-1406-0

[9] Kushwaha, J., Srivastava, V and Mall, I. Treatment of dairy wastewater by commercial activated carbon and bagasse fly ash: Parametric, kinetic and equilibrium modelling, disposal studies. Bioresour Technol, vol. 101, no. 10, pp.3474-3483, May 2010. https://doi.org/10.1016/j.biortech.2010.01.002

[10] Khataee, A., Vafaei, F and Jannatkhah, M. Biosorption of three textile dyes from contaminated water by filamentous green algal Spirogyra sp.: Kinetic, isotherm and thermodynamic studies. Int Biodeterior Biodegradation, vol. 83, pp.33-40, September 2013. https://doi.org/10.1016/j.ibiod.2013.04.004

[11] Chowdhury, Z., Zain, S and Rashid, A. Equilibrium Isotherm Modeling, Kinetics and Thermodynamics Study for Removal of Lead from Waste Water. E- J. Chem 2011, vol. 8, no. 1, pp.333-339, August 2011. https://doi.org/10.1155/2011/184040

[12] Rodríguez, J., Lema, J and Kleerebezem, R. Energy-based models for environmental biotechnology. Trends Biochem Sci, vol. 26, no. 7, pp.366-374, July 2008. https://doi.org/10.1016/j.tibtech.2008.04.003

[13] Lüttge, A. Crystal dissolution kinetics and Gibbs free energy. J Electron Spectros Relat Phenomena, vol. 150, no.2-3, pp.248-259, February 2006.

https://doi.org/10.1016/j.elspec.2005.06.007

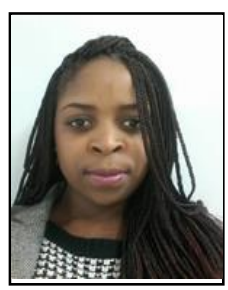

Ncumisa Mpongwana was born in Tsolo Eastern Cape in 1989 in December; she completed her high school at Oscar Mpetha High in Nyanga East, Cape Town in 2008. In 2009 she registers at Cape Peninsula University of Technology (CPUT) for undergraduate diploma in Biotechnology and completed it in 2013. In 2011 she voluntarily worked at Bioresource Engineering Research Group (BioERG) as a research assistant, assisting master and Ph.D. students with the microbiological and molecular work of their projects. During this time, she participated in various projects. In January 2012, she enrolled for Baccalaureus Technologiae (BTech) Biomedical Technology 
(Biotechnology) which was awarded in 2015 March. In January 2015 she enrolled for Master of Engineering (M-Eng) which she completed within a stipulated minimum period of 2 years with an average $>75 \%$ (Cum laude) chemical engineering at CPUT. During the course of her masters she published 2 journals and 2 book chapters and presented her work at a 7th Eastern Europe Young Water Professional conference which was held in Belgrade, Serbia on the 16 September 2015 - 19 September 2015, and YWP-ZA Biennial, \& 1st African IWA YWP Conference which was held in South Africa, Pretoria on the 16 November 2015 -19 November 2015. She registered for a Doctoral degree: Chemical engineering at CPUT in January 2017. Up to date, she has 7 publications. 